\title{
NCF2 Gene
}

National Cancer Institute

\section{Source}

National Cancer Institute. NCF2 Gene. NCI Thesaurus. Code C104563.

This gene plays a role in the generation of superoxide in neutrophils. 